\title{
Seasonal variation at four loci in a continuously breeding population of Danaus plexippus L.
}

\author{
M. P. ZALUCKI, J. M. HUGHES, * J. M. ARTHUR* \& P. A. CARTER $\dagger$ \\ Department of Entomology, University of Queensland, Brisbane, 4072 Australia, *School of Australian Environmental \\ Studies, Griffith University, Nathan, 4111, Australia and TEPO Biology, University of Colorado, Boulder, CO 80309,
}

U.S.A.

\begin{abstract}
Temporal genetic variation in a continuously breeding population of monarch butterflies, Danaus plexippus, was assessed by sampling two milkweed patch sites for about 2 years. Variation was determined at four loci; Pgm, Pgi, Idh and $\mathrm{Hbdh}$. Large changes in heterozygote and allele frequencies where observed between sample dates and between dates grouped into three 'seasons' (early summer, late summer, and winter). Both sites showed similar changes, but the question of 'seasonality' will require a longer period of study.
\end{abstract}

Keywords: Danaus plexippus, seasonal genetic variation.

\section{Introduction}

Most studies of genetic variation concentrate on genetic differences on a spatial (e.g. Stearns \& Sage, 1980; Smith et al., 1983a; Hughes \& Zalucki, 1984; McClenaghan et al., 1985) or on a temporal scale (e.g. Yardley et al., 1974; Mitton \& Koehn, 1975; Nyman, 1975; Nevo et al., 1977; Smith et al., 1983b), usually in response to directional selection following man-made changes in the environment.

There have been relatively few studies that have addressed the question of seasonal changes in gene frequency. Temporal changes in the genetic characteristics of various fish (Johnson, 1971, 1977; Koehn et al., 1971), Drosophila (Berger, 1971; Dobzhansky \& Ayala, 1973; Steiner, 1979; Carvener \& Clegg, 1981) and Colias butterflies (Watt, 1977, 1983; Watt et al., 1983) have been associated with seasonal or annual changes in temperature; although in some cases no regular seasonal variation was found (Carvener \& Clegg, 1981). Temporal changes, between seasons in small mammal populations (e.g. Semenoff \& Robertson, 1968; Gaines et al., 1978) have been related to changes in age structure (Charlesworth, 1980). In birds, temporal changes have rarely been detected (Redfield et al., 1972; Evans, 1987) perhaps reflecting, in part, the relatively long generation time in birds, although spatial variation is not uncommon (e.g. Redfield, 1973. 1974; Evans. 1987).
We have previously studied spatial and temporal variation in gene frequency in a population of Danaus plexippus L. (monarchs) in south-east Queensland, Australia (Hughes \& Zalucki, 1984; Zalucki et al., 1987; Carter et al., 1989). In this part of its range, the monarch breeds all year round (Zalucki, 1986). Our studies indicate that spatial samples taken at different times of the day (Hughes \& Zalucki, 1984), and on days with different conditions (Zalucki et al., 1987), reflect in part the varying propensities and abilities of different individuals to fly under such conditions (Hughes et al., 1992). Sampling at one site at different times of the day, we find significantly more heterozygotes at the $P g m$ and $P g i$ loci in samples taken early in the day (Carter et al., 1989).

Here we report on changes in allele and heterozygote frequency over 2 years at two regularly monitored sites. From our earlier studies we expected changes in heterozygotes frequency and frequency of some alleles with season.

\section{Materials and methods}

\section{Study sites}

Two sites were regularly sampled for almost 2 years. Both sites were in similar locations: rolling hills, cleared of their original vegetation for grazing, except along creek beds. Both contained large areas of milk- 
weed growing in patches of various sizes and as scattered plants. The predominant milkweed species was Asclepias fruticosa L. with a few A. curassavica L. along creeks. One site near Mt Crosby $\left(27^{\circ} 32^{\prime} \mathrm{S}, 152^{\circ}\right.$ $49^{\prime} \mathrm{E}$ ) contained a large area of milkweed and consequently a large monarch population. The other site was $\sim 8 \mathrm{~km}$ to the east in the outer Brisbane suburb of Brookfield $\left(27^{\circ} 31^{\prime} \mathrm{S}, 152^{\circ} 55^{\prime} \mathrm{E}\right)$. The sites will be referred to as $\mathrm{MC}$ and $\mathrm{BF}$, respectively. Meteorological conditions (Fig. 1) were taken from records of the Australian Meteorological Station at Amberley $(\sim 15$ km SSW of Mt Crosby).

\section{Sampling}

The sampling period ran from 27 February 1985 to 17 December 1986 for BF and 19 February 1985 to 23 December 1986 for MC. Both sites could not be sampled sequentially on the same day as earlier work indicated this would result in samples from different subpopulations. Every effort was made to sample on days with similar weather conditions (as far as this is possible in different seasons), and at a time of day when all the butterflies could have flown, i.e. air temperatures were above their flight threshold $\left(-15^{\circ} \mathrm{C}\right)$ or they had been exposed to sufficient solar radiation to raise their thoracic temperature so as to be capable of flight. Thus during the summer, sampling was generally from 08.00 to 09.00 hours and in winter from 09.30 to 10.30 hours (see Fig. 5, below). Butterflies were handnetted, stored in envelopes in a cool place and brought back to the laboratory for electrophoresis. Each site was systematically traversed by two or three samplers for 2
2 person-hours of netting effort. Unlike our previous studies examining the effects of time of day, when only active individuals were sampled, an attempt was made to catch any butterfly (whether it was active or inactive when seen) so as to avoid bias, and any variation in sampling effort was recorded.

\section{Electrophoresis}

All butterflies for electrophoresis were kept alive prior to processing, usually within $24-48 \mathrm{~h}$ of collection. Each butterfly was sexed and the abdomen and thorax were removed and homogenized separately in $0.5 \mathrm{ml}$ of buffer $(0.02 \mathrm{~m}$ Tris, $0.001 \mathrm{~m}$ EDTA, $0.01 \mathrm{~m}$ Ammonium chloride, $0.1 \mathrm{~m}$ glucose and 0.02 per cent sodium azide). Samples were spun below $4^{\circ} \mathrm{C}$ at 10,000 r.p.m. for $20 \mathrm{~min}$ in a Sorval RC5B centrifuge. The supernatant was decanted into vials and run immediately.

Electrophoresis was performed on cellulose acetate plates (Titan III Helena Laboratories). For phosphoglucosemutase $(P g m)$, glucose phosphate isomerase (Pgi) and isocitrate dehydrogorase (Idh), $0.1 \mathrm{~m}$ Tris citrate $\mathrm{pH} 7.0$ was used as an electrode buffer and for hydroxybutrate dehydrogenase $(H b d h), 0.1$ м Tris glycine $\mathrm{pH} 8.5$ was used. The latter (with two alleles) was scored from abdominal tissues, whilst better resolution of Pgm, Pgi and Idh (each with three alleles) was obtained using thoracic tissues.

\section{Statistical analysis}

For each sample day, each locus was checked for Hardy-Weinberg. Analyses of temporal variation in

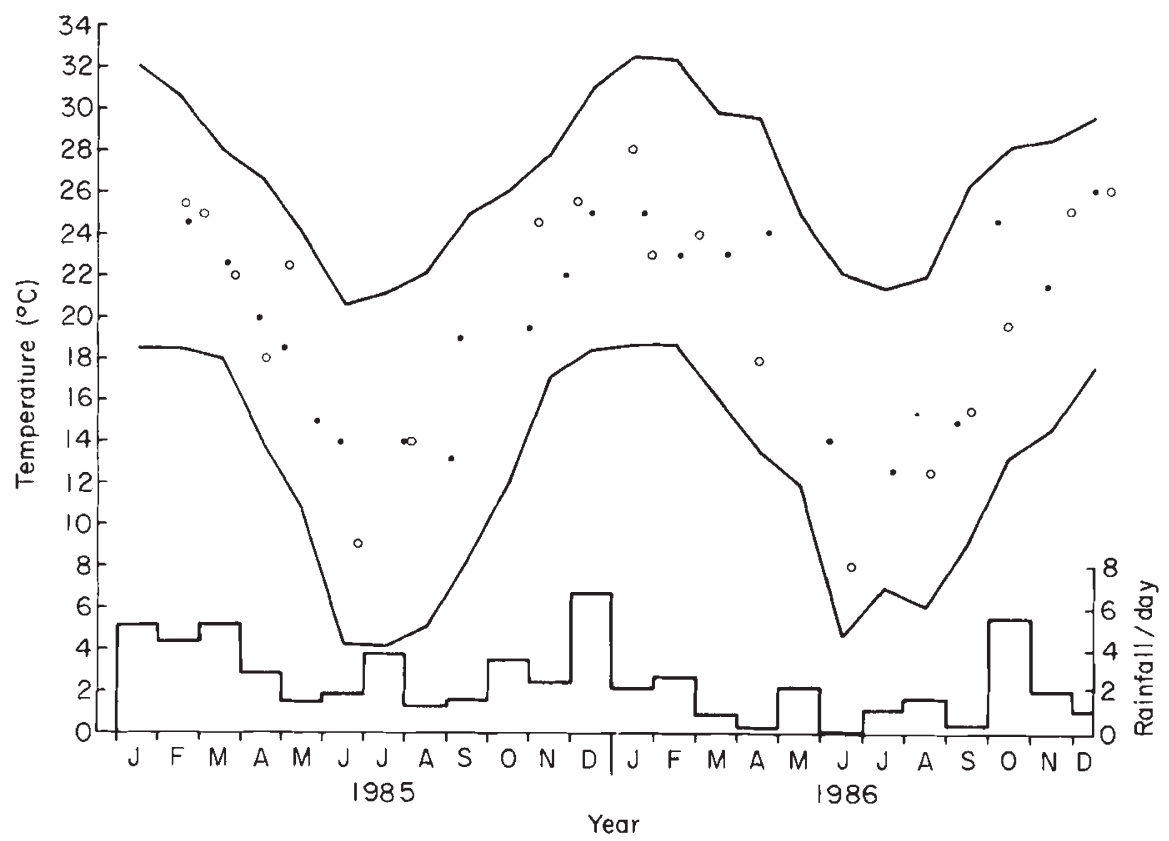

Fig. 1 Seasonal variation in average monthly maximum and minimum temperatures and total monthly rainfall during the study period. The average ((maximum and minimum)/2) temperature conditions on each sampling day for $\mathrm{MC}(\mathrm{O})$ and $\mathrm{BF}(\bullet)$ are also shown. 
heterozygote frequencies were done with each sample date included. To assess seasonal changes in allele frequencies using log-linear models (Feinberg, 1980), samples were grouped into periods of similar climatic conditions of early summer, late summer and winter, to give three seasons (in two cycles, Fig. 2) mainly to ensure sufficient numbers for analysis. The effect of the following factors (levels): place $(\mathrm{MC}, \mathrm{BF})$, year $(1,2)$, time $(1=$ early summer, $2=$ late summer, 3 =winter $)$, sex $(1,2)$ on allele frequency was determined. Firstly the best fit model to describe the data was selected by combining factors and interactions until no further improvement in fit was obtained $(P>0.05)$. By hierarchically fitting models the effect of each significant interaction could be assessed. Only those interactions involving allele or heterozygote with time or year will be presented here.

\section{Results}

\section{Changes in population parameters and 'seasonality'}

During the course of the study the monarch population turned over 18 times. This figure is based on the total day degrees elapsed from the start to the end of the project divided by the generation time (egg to newly emerged adult for monarchs 350DD; Zalucki, 1982). Conditions within any one 'season' are reasonably uniform for each site as were conditions on the day of sampling within a period. Winters (May-September) were cool and dry (Fig. 1), early summer (October-December) somewhat warmer and late summer (January-March) hot and wet (Fig. 1).

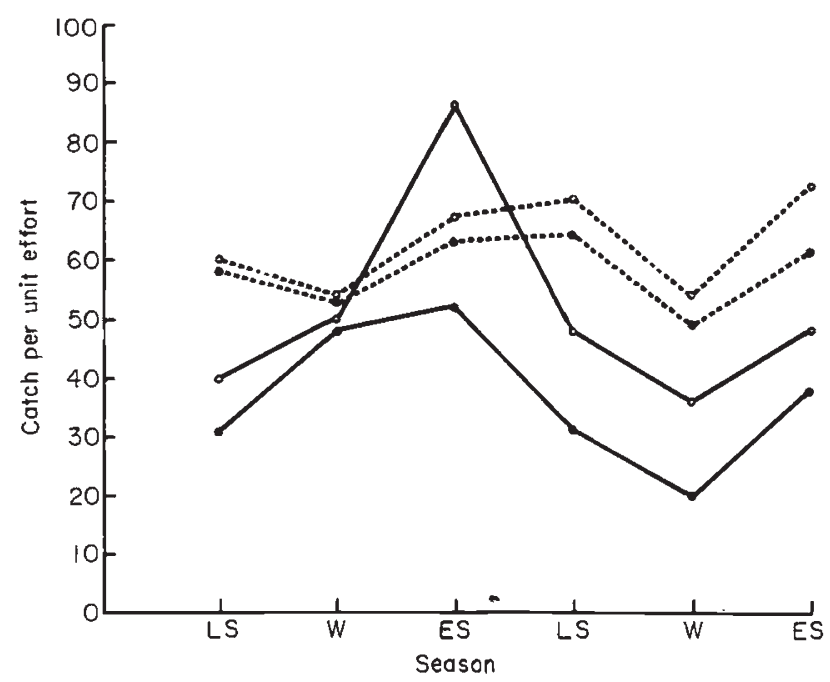

Fig. 2 Changes in index of abundance and sex ratios at two sites by season. (0) Mt Crosby, (•) Friary, (_-) population size, $(---)$ per cent male.
We have expressed the numbers caught in each season as a catch per unit effort in Fig. 2. Both sites show similar changes in abundance $\left(r_{\mathrm{c}}=0.802, n=6\right.$, $P<0.001)$ over the study period. Numbers generally increased to a peak in early summer, declining in late summer and into winter before picking up again. Numbers were generally higher at MC (Fig. 2), (which was also the larger in terms of area of milkweed). The sex ratio of sampled populations also showed similar changes in both sites $r_{\mathrm{c}}=0.911, P<0.001, n=6$; Fig. $2)$. The populations were male biased in early and late summer $(\sim 60$ per cent male) and declined to a 50:50 sex ratio in winter (Fig. 2).

\section{Temporal changes in heterozygotes and allele frequency}

Collection dates for each site, average sample size and the proportion of heterozygotes at each of the four polymorphic loci assayed (Idh, Pgm, Pgi, Hbdh) are summarized in Fig. 3. Only nine out of a total of 164 of the samples did not agree with HardyWeinberg, which does not differ from the expected number of significant departures due simply to chance, if a 95 per cent significance level is used. The number of animals scored for each locus was generally high, with a total of 1360 animals taken at MC and 750 at BF over 20 and 21 sampling occasions, respectively. (Average sample size for $\mathrm{MC}=68$, range 20-283; for $\mathrm{BF}=36,11-71$.) The large sample size at $\mathrm{MC}$ on 5.12.86 represented a larger catching effort as part of a mark-recapture study (Hughes et al., 1992). In general sample sizes were larger at MC (see above) and greater confidence can be placed in heterozygote and allele frequencies for this site (see below).

Although there was much variation, in some cases from one sample date to another, there also appear to be some cyclic trends in heterozygote frequencies (Fig. $3 a$ and $b$ ). A log-linear analysis of heterozygote frequency indicated significant interactions with time of year (= season) for Pgm at both sites (Fig. 3a and b) and $H b d h$ at BF only (Fig. 3b, Table 1 ), and year for $P g i$ (Table 1). There was a significant four-way interaction for $I d h$ and we leave its unravelling to the analysis of allele frequencies (below).

Log-linear analysis of allele frequencies (Table 2) indicated varying patterns with different loci. For Pgi only two-way interactions between allele with time of year, and allele with year were significant, indicating overall differences between year and time of year, and that these were the same at both sites (Fig. 4a). For Pgm the significant three-way interaction (Table 2) was due to differences between times in the first year but not the second, and differences between years in the first 

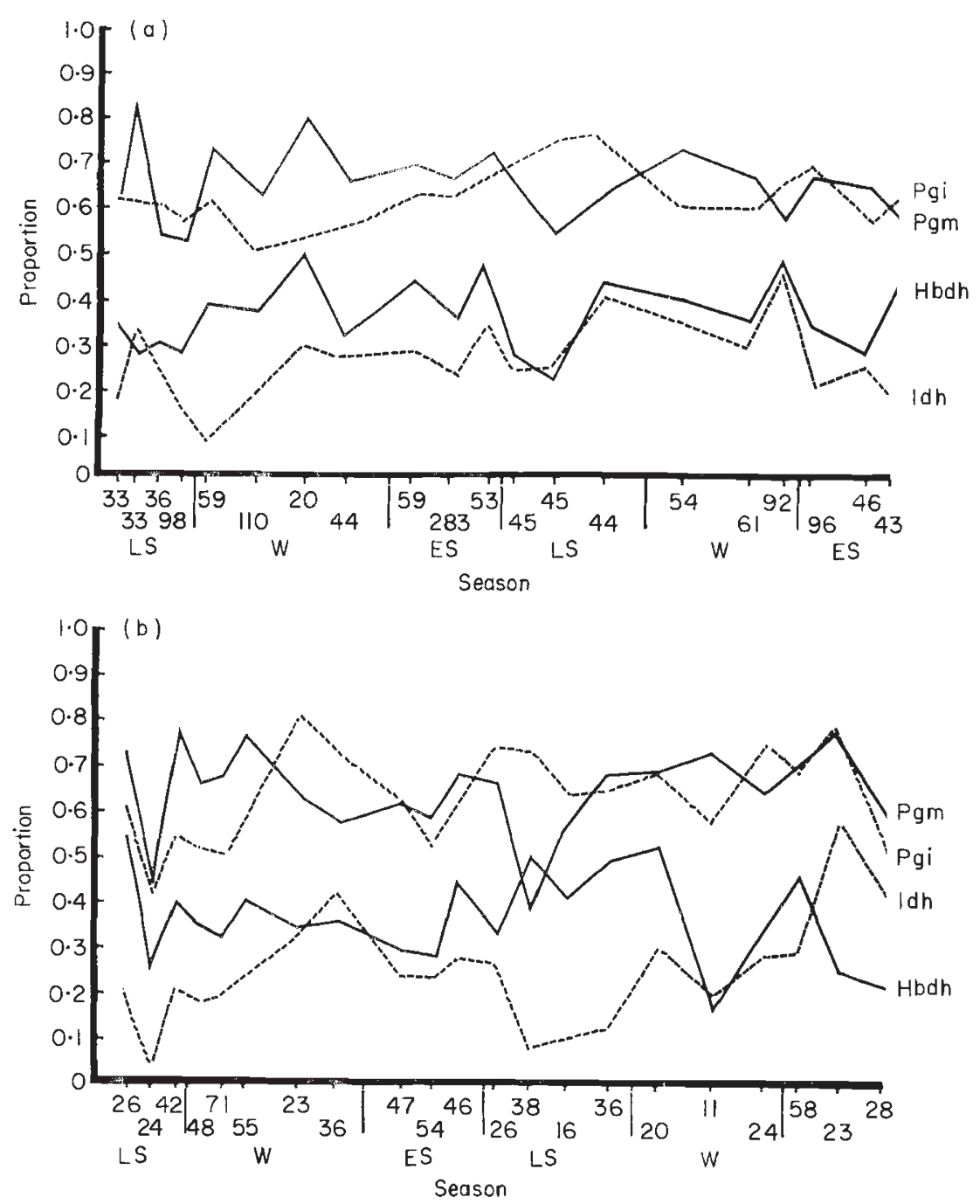

Fig. 3 Changes in heterozygote levels by sample date for four polymorphic loci at $M C(a)$ and $B F(b)$. Average sample size at each site is also shown as is the grouping of dates for subsequent seasonal analysis. season (but not the others) (Fig. 4b). For $H b d h$ there were two significant three-way interactions (Table 2), due to a difference between times of year in year 2 at MC only (Fig. 4c). Idh is complex, with a significant four-way interaction between allele, site, year and time of year (Fig. 4d). At each site there was a significant three-way interaction between allele, year and time of year. For MC there were differences between times of year in the second year, and differences between years for the first two seasons (early and late summer). For $\mathrm{BF}$ there were differences between time of year in the first year, and differences within early summer and winter between years (Table 2).

On balance the analysis of heterozygote and allelic frequencies shows significant temporal variation, some of which may be related to season and presumably climate.

Relating genetic changes to climate variables is not straightforward. It is not clear which measures of 'climate' are relevant to an animal and most climatic variables are also correlated. Here we use degree-days (DD), which is a measure of physiological time available for monarchs (Zalucki, 1982). This physiological measure of time is related to the amount of heat input that accumulates above a lower threshold $\left(11.5^{\circ} \mathrm{C}\right)$ during some specified time between sampling periods, based on the daily maximum and minimum temperatures. Not unexpectedly, DD was correlated with average inter-sample maxima and minima (e.g. For MC maximum temperature vs DD, $r=0.983$; minimum temperature vs $\mathrm{DD}, r=0.945)$. Our approach may mask the effects of periods of extreme maximum and minimum temperatures. Significant correlations of heterozygote and allele frequencies with DD are shown in Table 3.

The correlation coefficients did not differ between sites, except for the slow allele at the Pgm locus and allele frequencies for $H b d h$ (Table 3a). Significant positive association with DD occurred for heterozygotes of $P g i$ and the slow allele of Pgi at MC (Table 3a). There 
was a negative association for heterozygotes for Pgm at $\mathrm{BF}$, and the fast and slow alleles at Pgm at MC (Table 3a). A negative association for heterozygotes of $\mathrm{Hbdh}$ at $\mathrm{MC}$ and the fast allele at MC is also indicated (Table 3a). As no correlation differed significantly between sites this suggests that there is a relationship between temperature and heterozygote and/or allele frequencies for the Pgi, Pgm and Hbdh loci (Table 3a).

Table 1 Log-linear analysis showing all significant interactions of heterozygote frequency $(\mathrm{H})$ with time $(\mathrm{T}=$ season$)$, year $(\mathrm{Y})$ and place $(\mathrm{P}=$ sampling sites; $\mathrm{P} 1=\mathrm{Mt}$ Crosby, $\mathrm{P} 2$ = Brookfield site) for four polymorphic loci

Locus

\begin{tabular}{llll}
\hline Pgm & Pgi & Hbdh & Idh $\ddagger$ \\
\hline $\mathrm{H} \times \mathrm{T}$, & $\mathrm{H} \times \mathrm{Y}$, & $\mathrm{H} \times \mathrm{T} \times \mathrm{P}$, & $\mathrm{H} \times \mathrm{T} \times \mathrm{Y} \times \mathrm{P}$, \\
$7.6(1)^{* *}$ & $11.67(1)^{* * *}$ & $10.90(2)^{* * *}$ & $12.37(2)^{* * * *}$ \\
& & $\mathrm{P} 1: \mathrm{ns}$ & \\
& & $\mathrm{P} 2: \mathrm{H} \times \mathrm{T}$ & \\
\hline
\end{tabular}

$\ddagger$ Idh analysed fully using alleles, see text and Table 2 .

$G$-statistic given and degrees of freedom in brackets, ns $=$ not significant, ${ }^{*} P<0.05,{ }^{* *} P<0.01,{ }^{* * *} P<0.001$.
Combining data for both sites (Table 3b), the negative association for heterozygotes at the Pgm locus remain, as does the positive association for the slow allele at $P g i$ but not for the heterozygote frequency for $H b d h$ (Table 3b). Some caution has to be used in interpreting the combined data, as the low sample size at the BF site on most sampling occasions means less precision can be attributed to frequency estimates at this site.

\section{Discussion}

The pattern of variation of population size and sex ratio over 2 years was similar to that recorded by Zalucki \& Kitching (1984): high populations in late winter and early summer declining in late summer; and male-biased sex-ratios for most of the year but becoming female biased or 50:50 in late summer. The male-biased sex ratios around patches can be accounted for (in part) by patches of host plants acting predominantly as mating sites (Robinson, 1988; Zalucki, 1992). The seasonal changes in abundance can, in part, be accounted for by seasonal parasitism levels (Zalucki, 1981). Parasitism rates of larvae by tachinids are low throughout winter and increase to very high levels ( 100 per cent) by the end of summer. Zalucki \& Kitching (1982) could not find any season-

Table 2 Log-linear analysis showing all significant interactions of allele frequency (A) with time ( $\mathrm{T}=$ season), year $(\mathrm{Y})$, and place $(\mathrm{P}=$ sampling sites $)$ and $G$-statistic (degrees of freedom) and level of significance shown for significant interactions only (see Table 1)

\begin{tabular}{|c|c|c|c|}
\hline \multirow[b]{2}{*}{ Locus } & \multicolumn{3}{|l|}{ Interactions } \\
\hline & 4-way & 3-way & 2-way \\
\hline$P g i$ & - & - & $\begin{array}{l}\mathrm{A} \times \mathrm{T}, 38.1(4)^{* * *} \\
\mathrm{~A} \times \mathrm{Y}, 8.63(2)^{*}\end{array}$ \\
\hline$P g m$ & - & $\mathrm{A} \times \mathrm{Y} \times \mathrm{T}, 9.64(4)^{*}$ & $\begin{array}{l}\mathrm{Y}_{1}: \mathrm{A} \times \mathrm{T}, 27.60(4)^{* *} \\
\mathrm{~T}_{1}: \mathrm{A} \times \mathrm{Y}, 11.58(2)^{*}\end{array}$ \\
\hline$H b d h$ & - & $\begin{array}{l}\mathrm{A} \times \mathrm{Y} \times \mathrm{T}, 7.00(2)^{*} \\
\mathrm{~A} \times \mathrm{T} \times \mathrm{P}, 11.63(2)^{*}\end{array}$ & $\mathrm{P}_{1} \mathrm{Y}_{2}: \mathrm{A} \times \mathrm{T}, 10.76(2)^{*}$ \\
\hline \multirow[t]{2}{*}{$I d h$} & $\mathrm{~A} \times \mathrm{P} \times \mathrm{Y} \times \mathrm{T}, 13.8(4)^{*}$ & $\mathrm{P} 1: \mathrm{A} \times \mathrm{Y} \times \mathrm{T}, 16.93(4)^{* *}$ & $\begin{array}{l}\mathrm{Y}_{2}: \mathrm{A} \times \mathrm{T}, 10.43(4)^{*} \\
\mathrm{~T}_{1}: \mathrm{A} \times \mathrm{Y}, 9.92(2)^{*} \\
\mathrm{~T}_{2}: \mathrm{A} \times \mathrm{Y}, 38.44(2)^{* * *}\end{array}$ \\
\hline & & $\mathrm{P} 2: \mathrm{A} \times \mathrm{Y} \times \mathrm{T}, 10.43(2)^{*}$ & $\begin{array}{l}\mathrm{Y}_{1}: \mathrm{A} \times \mathrm{T}, 17.06(4)^{* *} \\
\mathrm{~T}_{1}: \mathrm{A} \times \mathrm{Y}, 27.21(2)^{* * *} \\
\mathrm{~T}_{3}: \mathrm{A} \times \mathrm{Y}, 7.00(2)^{*}\end{array}$ \\
\hline
\end{tabular}

Values after a particular factor as follows:

$\mathrm{P}, 1=$ Mt Crosby, 2 = Brookfield site; $\mathrm{Y}, 1=$ Year one, $2=$ Year two; $\mathrm{T}, 1=$ early summer, 2 = late summer, $3=$ winter. 

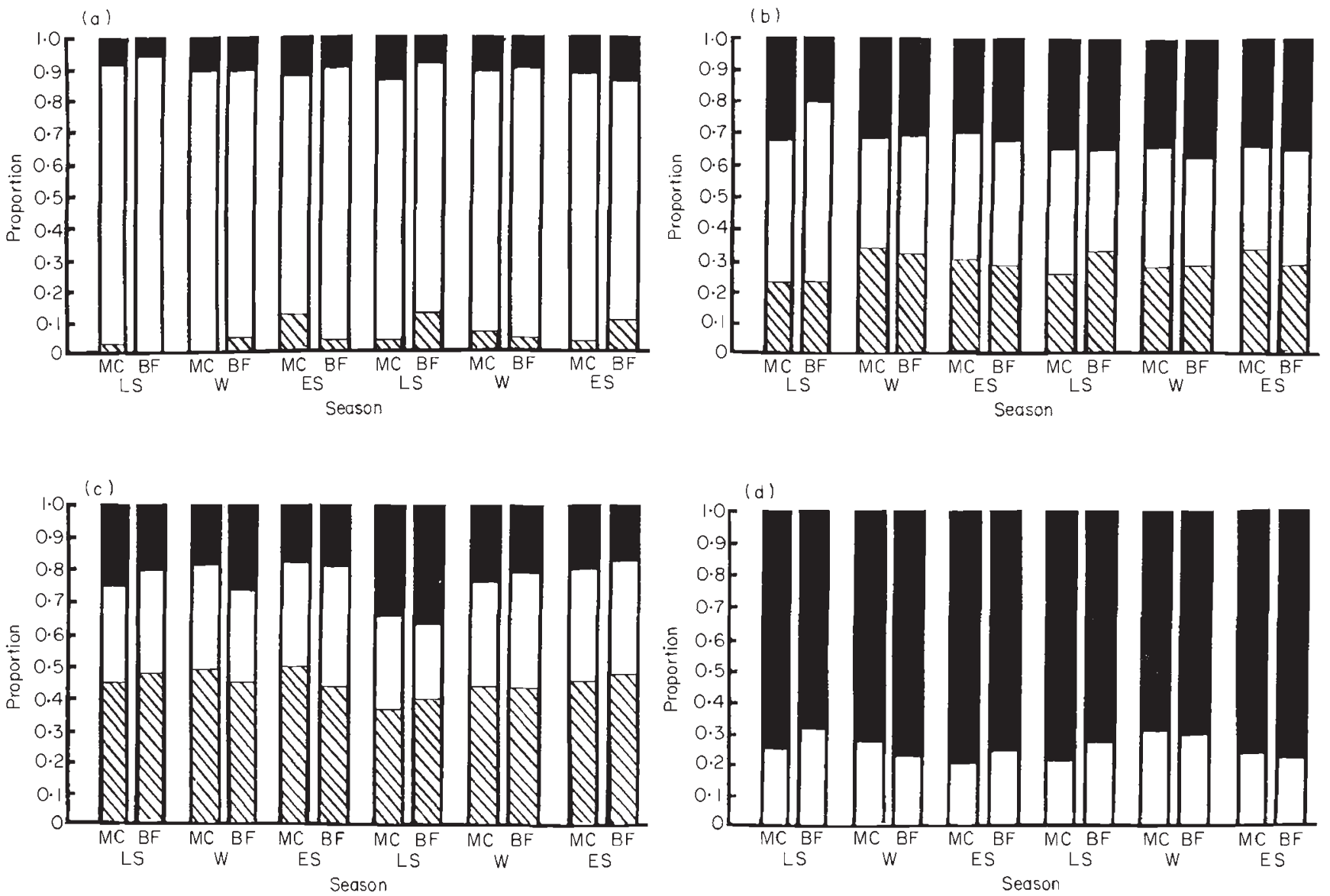

Fig. 4 Allele frequency at four polymorphic loci: $\operatorname{Idh}(\mathrm{a}), \operatorname{Pgm}(\mathrm{b}), \operatorname{Pgi}(\mathrm{c})$ and $H b d h(\mathrm{~d})$, at each of two sites (MC, BF) for seasonal grouping of sample dates $(\mathrm{LS}=$ late summer, $\mathrm{W}=$ winter, $\mathrm{ES}=$ early summer $)$.

ality in immature survival due to factors other than parasitism. Malcolm et al. (1988) suggested that temperatures consistently above $31^{\circ} \mathrm{C}$ may be inimical to population survival based on studies of immature and adult abundance in Florida (U.S.A.). This agreed with the findings of Rawlins \& Lederhouse (1981) and Zalucki $(1982)$ that high temperatures $\left(31-35^{\circ} \mathrm{C}\right)$ and $30^{\circ} \mathrm{C}$ (constant, laboratory) are inimical to larval survival. This may further account for the decline in adult monarch population size in late summer when maximum temperatures may exceed $31^{\circ} \mathrm{C}$. In the current study maximum temperatures exceeded $31^{\circ} \mathrm{C}$ for 3-5 day periods. If high temperatures differentially affect males then this could also account for the decline in sex ratios around patches at this time of the year.

Are there seasonal changes in the genetic structure of monarch populations? The diurnal pattern of temperature variation over the seasons in Brisbane is shown in Fig. 5. Taking $15^{\circ} \mathrm{C}$ as the flight threshold temperature for monarchs (Masters et al., 1988) and $31^{\circ} \mathrm{C}$ as an upper threshold for activity then the time available for oviposition, mating, feeding etc., by monarchs would be constrained in winter and summer, but more so in winter. If animals with certain genotypes are able to become active at lower temperatures then these would be favoured in winter. In summer temperatures become warm rapidly, flight threshold is exceeded early, and no genotype would be greatly disadvantaged in terms of activity time (see also Hughes et al. (1992).

From an earlier study (Carter et al., 1989) we found that heterozygotes were more active early in the day. This may mean that in winter heterozygotes would have more time available for mating and oviposition than homozygotes. However, this would not necessarily result in increased numbers of heterozygotes in succeeding generations because segregation would produce offspring with both homozygous and heterozygous genotypes. If, however, the heterozygotes had some other advantage, such as higher survival rates in low temperatures as larvae or adults, then heterozygote frequencies would be expected to increase within each generation in winter. At a number of loci, there do appear to be more heterozygotes in winter (Idh, Pgi, 
Table 3 Correlation analysis of proportion heterozygote (Het.) and allele frequency (F,M,S) for four polymorphic loci (arcsin $\sqrt{ }$ transformed) versus Day Degrees for the intersampling period for two sites ( $\mathrm{MC}=$ Mount Crosby, $n=20 ; \mathrm{BF}=$ Brookfield, $n=21$ ) separately (a) and combined where coefficients were not significantly different between sites $(b)$

\begin{tabular}{|c|c|c|c|c|c|}
\hline \multirow[b]{2}{*}{ Proportic } & & \multicolumn{4}{|l|}{ Locus } \\
\hline & & $P g i$ & Pgm & $I d h$ & $H b d h$ \\
\hline \multicolumn{6}{|c|}{ (a) Separate analysis } \\
\hline \multirow[t]{2}{*}{ Het. } & $\mathrm{MC}$ & $0.452^{* *, a}$ & $-0.124^{\mathrm{ns,a}}$ & $-0.12^{\mathrm{ns}, \mathrm{a}}$ & $-0.399^{*, a}$ \\
\hline & $\mathrm{BF}$ & $-0.106^{\mathrm{ns}, \mathrm{a}}$ & $-0.375^{*, \mathrm{a}}$ & $-0.356^{\mathrm{ns}, \mathrm{a}}$ & $0.054^{\mathrm{ns}, \mathrm{a}}$ \\
\hline \multirow[t]{2}{*}{$F$} & MC & $-0.313^{\mathrm{ns}, \mathrm{a}}$ & $-0.391^{*, a}$ & $0.086^{\mathrm{ns}, \mathrm{a}}$ & $-0.521^{*, a}$ \\
\hline & $\mathrm{BF}$ & $-0.024^{\mathrm{ns}, \mathrm{a}}$ & $-0.085^{\mathrm{ns}, \mathrm{a}}$ & $0.167^{\mathrm{ns}, \mathrm{a}}$ & $0.295^{\mathrm{ns}, \mathrm{t}}$ \\
\hline \multirow[t]{2}{*}{ M } & MC & $-0.294^{\mathrm{ns}, \mathrm{a}}$ & $0.162^{\text {ns.a }}$ & $-0.013^{\mathrm{ns}, \mathrm{a}}$ & - \\
\hline & $\mathrm{BF}$ & $-0.171^{\mathrm{ns}, \mathrm{a}}$ & $0.265^{\mathrm{ns}, \mathrm{a}}$ & $0.07^{\mathrm{ns}, \mathrm{a}}$ & - \\
\hline \multirow[t]{2}{*}{ S } & MC & $0.535^{*, \mathrm{a}}$ & $0.378^{*, a}$ & $0.045^{\mathrm{ns}, \mathrm{a}}$ & $0.521^{*, a}$ \\
\hline & $\mathrm{BF}$ & $0.159^{\mathrm{ns,a}}$ & $-0.310^{\mathrm{ns}, \mathrm{b}}$ & $-0.168^{\mathrm{ns}, \mathrm{a}}$ & $-0.281^{\mathrm{ns}, \mathrm{b}}$ \\
\hline \multicolumn{6}{|c|}{ (b) Combined $(n=41)$} \\
\hline \multicolumn{2}{|c|}{ Het. } & $0.093^{\mathrm{ns}}$ & $-0.264^{*}$ & -0.233 & -0.169 \\
\hline \multicolumn{2}{|l|}{$\mathrm{F}$} & -0.179 & -0.222 & 0.104 & - \\
\hline \multicolumn{2}{|l|}{ M } & -0.221 & 0.221 & 0.025 & - \\
\hline \multicolumn{2}{|l|}{$\mathrm{S}$} & $0.332 *$ & - & -0.178 & 一 \\
\hline
\end{tabular}

*Indicates coefficient different from $0(P<0.05)$. Coefficients followed by the same letter are not significantly different, $(P<0.05)$ in site comparisons for each allele and heterozygote.

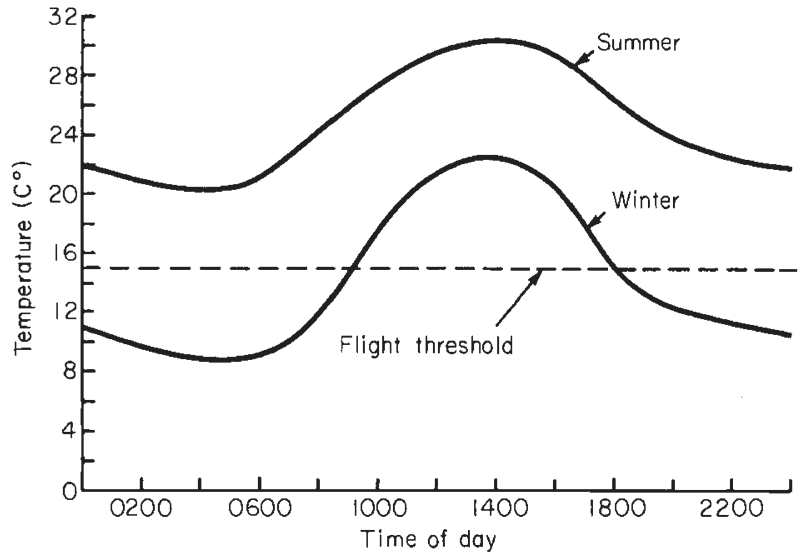

Fig. 5 Diurnal variation of temperature for the average summer and winter day at Amberley. Flight threshold temperature also shown.

Pgm, Fig. 3, although significantly so for Pgm and Idh only, Table 1. A significant negative relationship with temperature was observed for Pgm only, Table 3a, b. Interestingly, those are the same loci where significant differences in heterozygote frequency were identified with time of day (Carter et al., 1989).

In our previous studies we detected differences in heterozygote frequencies depending on the time of day a sample was taken (Carter et al., 1989). We do not believe this effect influenced the changes that we detected throughout the year in this study. In our time of day studies we deliberately set out to compare the genotypes of animals that were active early versus those in late samples; that is, we only caught active animals in our early samples. The percentage difference in heterozygote frequencies between early and late samples across different times of year ranged from 3 to 22 per cent (mean differences for $P g m=9$ per cent, range $=5-15, n=7 ; P g i=11$ per cent, $6-20$ and for $I d h=12$ per cent, 3-22). This is much lower than the temporal changes detected here for two sites: for $\mathrm{Pgm}$ the maximum changes were 33-43 per cent (MC \& BF respectively), Pgi, 22-40 per cent and $I d h$, 35-45 per cent.

The lack of a major effect of site in our log-linear analysis of heterozygote and allelic frequencies suggests either that populations are responding similarly to environmental changes or, alternatively, that butterflies at the two sites are simply subsets of a larger total population. A similar study examining temporal variation in Musca domestica found negligible correlation between sites and the researchers concluded that in their study the variation between sites was determined by small-scale habitat variability 
(Black \& Krafsur, 1986). Similarly, Wall et al. (1980) interpreted change in frequencies of banded snails at 15 sites as an effect of similar changes in selection pressures at all sites. In the present study it is not easy to differentiate between the two possibilities, as monarchs are capable of moving quite large distances (Zalucki, 1986) and thus we could be examining two samples of a single population.

An analysis of alleles by season indicates significant variation over time and possible seasonal patterns. Other studies have reported possible seasonal changes in gene frequencies in Drosophila (e.g. Berger, 1971; Dobzhansky \& Ayala, 1973; Steiner, 1979), while other more extensive studies reported no evidence of seasonal variation (Cavener \& Clegg, 1981). Watt and co-workers (Watt, 1977; Watt et al., 1983) found seasonal gene frequency changes in Colias butterflies which could be related to temperature and enzyme efficiency. Determining the seasonality of a phenomenon, based on 2 years' data, can never be conclusive or tested quantitatively (e.g. by time-series analysis), and in fact none of the papers above which deal with seasonality have more than 2 years' data!

To be able to understand the variation observed here, and in earlier papers, it is important to determine whether or not adult or larval susceptibility to extremes of temperature differs among genotypes. In addition, if individuals fly early because of their genotype, then particular individuals caught early on a given day should be more likely than those initially caught at a later time to be caught early on subsequent days. These factors are currently being examined.

\section{Acknowledgements}

Our thanks to Jocelyne Campbell for typing this manuscript. This work was supported by grants from ARGS and URG from GU and UQ. We wish to thank Paula Coutts for assistance with field and laboratory work. Gunter Maywald, CSIRO, provided data for temperature profiles in Fig. 5 and Bill Ballar made comments on on an earlier draft of the manuscript.

\section{References}

BERGER, E. M. 1971. A temporal survey of allelic variation in natural and laboratory population of Drosophila melanogasta. Genetics, 67, 121-136.

BLACK, IV, W. G. AND KRAFSUR, E. s. 1986. Temporal and spatial trends in allozyme frequencies in house fly populations, Musca domestica L. Theor. Appl. Genet., 71, 673-681.

CARTER, P. A., HUGHES, J. M. AND ZALUCK1, M. P. 1989. Genetic variation in a continuously breeding population of Danaus plexippus L.: an examination of heterozygosity at four loci in relation to activity times. Heredity, 63, 191-194.
CARVENER, D. R. AND CLEGG, M. T. 1981. Temporal stability of allozyme frequencies in a natural population of Drosophila melanogasta. Genetics, 98, 613-623.

Charlesworth, B. 1980. Evolution in Age-structured Populations. Cambridge University Press, London.

DOBZHANSKY, T. AND AYALA, F. J. 1973. Temporal frequency changes of enzyme and chromosome polymorphisms in natural populations of Drosophila. Proc. Natl. Acad. Sci., U.S.A., 70, 680-683.

EVANS, P. H. G. 1987. Electrophoretic variability of gene products. In: Cooke, F. and Buckley, P. A. (eds) Avian Genetics: A Population and Ecological Approach. Academic Press, London.

FEInBerg, S. E. 1980. The Analysis of Cross Classified Categorical Data. Massachussets Institute of Technology, U.S.A.

GAines, M. S., McClenAGHAN, L. R. AND RosE, R. K. 1978. Temporal patterns of allozymic variation in fluctuating populations of Microtus ochrogaster. Evolution, 32, 723-739.

HUGHES, J. M. AND ZALUCK1, M. P. 1984. Genetic variation in a continuously breeding populatin of Danaus plexippus L. (Lepidoptera: Nymphalidae). Heredity, 52, 1-7.

HUGHES, J. M., ZALUCKI, M. P. AND CARTER, P. A. 1992. Consistent differences among individual monarch butterflies (Danaus plexippus) in flight activity at low temperatures. Biol. J. Linn. Soc., 47, (in press).

JOHNSON, M. S. 1971. Adaptative lactate dehydrogenase variation in the crested blenny, Anoplarchus. Heredity, 27, 205-226.

JOHNSON, M. s. 1977. Association of allozymes and temperature in the crested blenny, Anoplarchus purpurenscens. Mar. Biol., 41, 147-152.

KOEHN, R. K., PEREZ, J. E. AND MERRITTS, R. B. 1971. Esterase enzyme function and genetic structure of populations of the freshwater fish, Notropis stramineus. Am. Nat., 105, 51-69.

McClENAGHAN, L. R. JR., SMITH, M. H. AND SMITH, M. W. 1985. Biochemical changes of mosquito fish IV. Changes of allele frequencies through space and time. Evolution, 39, $451-460$

MALCOLM, S. B., COCKERELL, B. J. AND BROWER, L. P. 1988. Monarch butterfly voltinism: effect of temperature constraints at different latitudes. Oikos, 49, 77-82.

MASTERS, A., MALCOLM, S. B. AND BROWER, L. P. 1988. Monarch butterfly (Danaus plexippus) thermoregulation behaviour and adaptation for overwintering in Mexico. Ecology, 69, 458-467.

MITTON, J. B. AND KOEHN, R. K. 1975. Genetic organisation and adaptive response of allozymes to ecological variables in Fundulus heteroclitus. Genetics, 79, 97-111.

NEVO, E., SHIMONY, T. AND LIBNI, M. 1977. Thermal selection of allozyme polymorphisms in barnacles. Nature, $\mathbf{2 6 7}$, 699-701.

NYMAN, L. 1975. Allelic selection in a fish Gymnocephalus cernua (L.) subjected to hot water effluents. Inst. Freshw. Res. Drottningholm, 54, 75-82.

RAWLiNS, J. E. AND LEDERHOUSE, R. C. 1981. Developmental influences of thermal behaviour on monarch caterpillars (Danaus plexippus): an adaptation for migration (Lepi- 
doptera: Nymphalidae: Danainae). J. Kansas Ent. Soc., 54, 387-408.

REDFIELD, J. 1973. Demographic and genetics in colonizing populations of Blue Grouse. Evolution, 32, 723-739.

REDFIELD, J. 1974. Genetics and selection at the $\mathrm{Ng}$ locus in the Blue Grouse (Dendragapus obscurus). Heredity, 31, $35-42$.

REDFIELD. J., ZWICKEL, F. C., BENDELL, J, F. AND BERGERUD, A. T. 1972. Temporal and spatial patterns of allele and genotype frequencies at the $\mathrm{Ng}$ locus in Blue Grouse (Dendragapus obscurus). Can. J. Zool., 50, 1657-1662.

ROBINSON, A. 1988. A comparison of different approaches to the modelling of sex ratios. Hons Thesis, Griffith University.

SEMENOFF, R. AND ROBERTSON, F. W. 1968. A biochemical and ecological study of plasma esterase polymorphism in natural populations in the field vole. Microtus agrestis L. Biochem. Genet., 1, 205-227.

SMITH, M. W., SMITH, M. H. AND CHESSER, R. K. 1983a. Biochemica! genetics of mosquito fish. I. Environmental correlates, and temporal and spatial heterogeneity of allele frequencies within a river drainage. Copeia, 1983, 182-192.

SMITH, M. H., SMITH, M. W., SCOTT, S. L. LIU, E. H. AND JONES, J. C. 1983b. Rapid evolution in a post-thermal environment. Copeia, 1983, 193-197.

STEINER, w. w. M. 1979. Genetic variation in Hawaiian Drosophila VI, Seasonally dependant gene changes in Drosophila mimica. Evolution, 33, 543-562.

STEARNS, S. C. AND SAGE, R. D. 1980. Maladaptation in a marginal population of the mosquito fish, Gambusia affinis. Evolution, 34, 65-75.

WALL, S., CARTER, M. A. AND CLARKE, B. 1980. Temporal changes of gene frequencies in Cepaea hortensis. Biol. J. Linn. Soc., 14, 303-317.

WATT, w. B. 1977. Adaptation at specific loci. I. Natural selection on phosphoglucose isomerase of Colias butter- flies: biochemical and population aspects. Genetics, 87, 177-194.

WATT, w. B. 1983. Adaptation at specific loci II. Demographic and biochemical elements in the maintenance of the Colias PGI polymorphism. Genetics, 103, 691-724.

WATT, W. B., CASSIN, R. C. AND SWAN, M. s. 1983. Adaptation at specific loci III. Field behaviour and survivorship differences among Colias PGI genotypes are predictable from in vitro biochemistry. Genetics, 103, 725-739.

YARDLEY, D. J., AVISE, J. C., GIBBONS, J. W. AND SMITH, M. H. 1974. Biochemical genetics of sunfish III. Genetic subdivision of fish populations inhabit heated waters. In: Gibbons, J. W. and Sharitz, R. R. (eds) Thermal Ecology. U.S. Atomic Energy Commission, Springfield, VA, pp. 255-253.

ZALUCKI, M. P. 1981. Temporal and spatial variation of parasitism in Danaus plexippus (L.) (Lepidoptera: Nymphalidae). Aust. Ent. Mag., 8, 3-8.

ZALUCKI, M. P. 1982. Temperature and rate of development in Danaus plexippus L. and D. chrysippus L. (Lepidoptera: Nymphalidae). J. A ust. Ent. Soc., 21, 241-246.

ZALUCKI, M. P. 1986. The monarch butterfly - a non-pest exotic insect. In: Kitching, R. L. (ed.) The Ecology of Exotic Animals and Plants. John Wiley, Brisbane.

ZALUCKI, M. P. 1992. Sex around the milkweed patch. In: Malcolm, S. B. and Zalucki, M. P. (eds) The Biology and Conservation of the Monarch Butterfly. L.A. Museum of Natural History, L.A.

ZALUCKI, M. P., HUGHES, J. M. AND CARTER, P. A. 1987. Genetic variation in Danaus plexippus L.: Habitat selection and differences in activity times. Heredity, 59, 213-221.

ZALUCKI, M. P. AND KITCHLING, R. L. 1982. Temporal and spatial variation of mortality in field populations of Danaus plexippus L. and $D$. chryrippus L. larvae (Lepidoptera: Nymphalidae). Oecologia, 53, 201-207.

ZALUCKI, M. P. AND KITChling, R. L. 1984. The dynamics and structure of a continuously breeding population of Danaus plexippus L. in south-east Queensland. J. Lepid. Soc., 38, 209-219. 